\title{
Pemanfaatan Limbah Cangkang Telur dan Tanaman Yodium (Jatropha mulitifida Linn) sebagai Salep Antiseptik Alami
}

\section{Utilization of Eggshell Waste and Yodium Leaves (Jatropha mulitifida Linn) as a Natural Antiseptic Ointment}

\author{
Muhammad Hamdani Saputra', Jaka', Reni Nuraeni', Debby Fadilah Pazra ${ }^{2}$ \\ ${ }^{1}$ Program Studi Penyuluhan Peternakan dan Kesejahteraan Hewan, Polbangtan Bogor \\ ${ }^{2}$ Program Studi Kesehatan Hewan, Polbangtan Bogor \\ *Korespondensi penulis : E-mail hamdanisaputra734@gmail.com
}

Diterima : Februari 2021

Disetujui terbit : Mei 2021

\begin{abstract}
This study aims to determine the combination of eggshell powder and plant Yodium as an ointment and the best dose of the ointment. The ointment is made with a combination of eggshell powder and Yodium plant extracts with concentrations of $15 \%, 20 \%, 25 \%$, and $30 \%$. The test parameters such as organoleptic, dispersion, $\mathrm{pH}$, homogeneity test and in vivo activity test. The organoleptic test was carried out by analyzing the odor, shape and color of the ointment preparation. The spreadability test was carried out by giving a load to the ointment preparation. The $\mathrm{pH}$ test was carried out by looking at the degree of acidity in the ointment preparation. Homogeneity test was carried out by looking at the level of homogeneity of the ointment preparation. In vivo tests were carried out on 21 local chickens which were given $1,5 \mathrm{~cm}$ incisions for 14 days. The wound healing diameter was analyzed using Analysis of Variance and continued with DMRT. The results of the dispersion test showed that the ointment preparations that were given a heavier load resulted in a wider diameter. The organoleptic test showed that the quality produced was quite good, indicated by the preparation of a semi-solid ointment, the ointment with a distinctive smell from the extract used and the color of the extract. In vivo test results show that the ointment is effective in healing wounds. The best concentration is the $30 \%$ formulation because it shows the fastest results in the wound healing process. These results indicate that eggshell waste and yodium leaves can be used as a natural antiseptic ointment for wound healing. Keywords: antiseptic ointment, egg shell, wound, yodium plant
\end{abstract}

\begin{abstract}
ABSTRAK
Penelitian bertujuan untuk mengetahui apakah kombinasi serbuk cangkang telur dan tanaman yodium dapat dijadikan salep serta dosis terbaik dari salep tersebut. Salep dibuat dengan kombinasi serbuk cangkang telur dan ekstrak tanaman yodium dengan konsentrasi $15 \%, 20 \%$, $25 \%$, dan $30 \%$. Parameter diukur dengan 5 macam uji yaitu uji organoleptik, uji daya sebar, uji $\mathrm{pH}$, uji homogenitas dan uji aktivitas secara in vivo. Uji organoleptik dilakukan dengan cara menganalisis bau, bentuk dan warna pada sediaan salep. Uji daya sebar dilakukan dengan cara memberi beban kepada sediaan salep. Uji pH dilakukan dengan melihat derajat keasamaan pada sediaan salep. Uji homogenitas dilakukan dengan melihat tingkat homogenitas sediaan salep. Uji secara in vivo dilakukan pada ayam lokal sebanyak 21 ekor yang diberi luka sayat sebesar 1,5 $\mathrm{cm}$ selama 14 hari. Diameter penyembuhan luka dianalisis menggunakan Anova dan dilanjutkan dengan uji lanjut Duncan. Hasil uji daya sebar memperlihatkan bahwa sediaan salep yang diberikan beban yang semakin berat menghasilkan diameter yang semakin lebar. Uji organoleptik memperlihatkan kualitas yang dihasilkan cukup baik ditandai dengan sediaan salep setengah padat, salep berbau khas ekstrak yang digunakan dan berwarna seperti ekstrak. Hasil uji in vivo menunjukkan bahwa salep efektif dalam menyembuhkan luka. Konsetrasi terbaik adalah dengan formulasi $30 \%$ karena menunjukkan hasil yang paling cepat dalam proses penyembuhan luka. Hasil ini menunjukkan limbah cangkang telur dan daun yodium dapat dijadikan sebagai salep antiseptik alami terhadap penyembuhan luka.

Kata kunci : cangkang telur, luka, salep antiseptik, tanaman yodium
\end{abstract}




\section{PENDAHULUAN}

\section{Latar Belakang}

Prinsip back to nature semakin populer pada era modern ini. Banyak orang berpaling ke pengobatan tradisional. Semakin meningkatnya kesadaran akan gaya hidup kembali ke alam tersebut, semakin banyak bahanbahan alami. Indonesia merupakan negara tropis yang mempunyai biodiversitas tinggi, kaya akan flora dan fauna yang dapat dijadikan sebagai obat, salah satunya adalah tanaman yodium (Jatropha multifida Linn) dan cangkang telur. Menurut Badan Pusat Statistika (BPS) produksi telur ayam pada tahun 2011 sebesar 1.027 .846 ton dan terus meningkat sampai tahun 2018 yaitu sebesar 1.644.460 ton (BPS 2018).

Menurut Suprapti (2002) secara umum telur terbagi atas tiga komponen pokok, yaitu cangkang telur $(11 \%$ dari bobot telur), putih telur (57\% dari bobot telur) dan kuning telur (32\% dari bobot telur). Bila $11 \%$ adalah cangkang telur maka, cangkang telur yang dihasilkan pada tahun 2018 adalah 180,89 ton. Peningkatan produksi telur ini tentu meningkatkan pula limbah cangkang telur. Namun produksi cangkang telur ini tidak sebanding dengan pemanfaatan limbahnya sehingga menyebabkan pencemaran pada lingkungan sekitar. Banyak manfaat yang dapat diperoleh dari cangkang telur. Salah satu manfaatnya yaitu cangkang telur dapat berfungsi mempercepat penyembuhan luka karena tersusun atas senyawa protein sederhana dan kalsium, yaitu kalsium karbonat sekitar 95\% (Warsy et al. 2013).

Tanaman yodium (Jatropha multifida Linn) merupakan salah satu tanaman obat yang sering digunakan masyarakat pedesaan sebagai obat luar seperti luka baru, bengkak dan mengatasi berbagai infeksi (Sariana 2013). Penduduk Nigeria menggunakan tanaman yodium (Jatropha multifida Linn) sebagai obat tradisional untuk mengobati berbagai jenis infeksi. Getah dan daunnya dapat digunakan untuk menyembuhkan infeksi pada lidah bayi dan juga dapat digunakan untuk mengobati infeksi luka pada kulit, sedangkan buah, biji, dan minyak dari biji tanaman yodium (Jatropha multifida Linn) dapat digunakan sebagai obat pencahar, mengobati luka berdarah, mencegah dan mengobati kerusakan gigi seperti karies gigi (Syarfati et al. 2011).

Tanaman yodium juga mengandung sulfur dan iodine yang berperan sebagai antiseptik dan mempercepat penyembuhan luka bakar (IImi 2009). Kandungan kimia dalam tanaman yodium yang memiliki khasiat antibakteri telah diketahui diantaranya 
adalah alkaloid, flavanoid, tanin dan saponin (Anonim 2000).

Adanya kandungan-kandungan zat yang berkhasiat menyembuhkan luka pada cangkang telur dan tanaman yodium tersebut, memunculkan suatu ide untuk mengombinasikannya menjadi sebuah produk kesehatan, yakni salep antiseptik alami.

\section{METODE PENELITIAN}

Penelitian ini dilaksanakan selama 3 minggu, dimulai pada November 2020 sampai Desember 2020 di Laboratorium Kesehatan Ternak Politeknik Pembangunan Pertanian Bogor.

Alat yang digunakan dalam penelitian ini diantaranya oven, blender, ayakan 250 mesh, timbangan digital, gelas kimia 500ml, inkubator, wadah 25 $\mathrm{ml}$, jangka sorong, mikroskop, kertas uji $\mathrm{pH}$, sentrifuge, gelas ukur, cover glass dan object glass.

Bahan yang digunakan dalam penelitian diantaranya ekstrak tanaman yodium, ethanol 96\%, minyak bulu domba, vaselin album, 21 ekor ayam lokal, cangkang telur, Ciprofloxacin, obat bius, aquades, alkohol $70 \%$.

\section{Pembuatan Serbuk Cangkang Telur}

Limbah cangkang telur ayam dibersihkan dan direndam dengan menggunakan air panas selama 10 menit dan selanjutnya dikeringkan dalam oven pada suhu $105{ }^{\circ} \mathrm{C}$ selama 30 menit. Setelah kering, cangkang telur dihaluskan dengan blender sampai menjadi serbuk yang halus. Serbuk cangkang telur diayak dengan ukuran 250 mesh (Sariyana et al. 2018).

\section{Ekstraksi Getah Tanaman Yodium}

Sampel tanaman yodium disortasi untuk memisahkan kotoran kemudian dicuci menggunakan air mengalir. Pencucian ini dilakukan untuk memastikan bahwa sampel yang akan digunakan dalam keadaan bersih. Setelah dicuci sampel didiamkan kemudian dilakukan proses pengeringan. Proses pengeringan dilakukan didalam oven dengan suhu $60^{\circ} \mathrm{C}$ selama 6 jam. Proses pengeringan bertujuan untuk mencegah bertumbuhnya kapang dan jamur sehingga diperoleh simplisia yang awet dan dapat disimpan dalam jangka waktu yang lama. Simplisia kemudian di blender dan diayak.

Serbuk tanaman yodium (daun dan batang) ditimbang sebanyak 400 gram dan dimaserasi 3×24 jam menggunakan pelarut metanol dengan perbandingan serbuk : pelarut (1:5) dalam bejana tertutup. Campuran didiamkan selama 3 hari sambil dilakukan pengadukan. Hasil maserasi dikumpulkan kemudian disaring. Filtrat yang diperoleh dipekatkan pada suhu $80{ }^{\circ} \mathrm{C}$, hingga 
diperoleh ekstrak kental (Rokhana dan Ainiyah 2019).

\section{Pembuatan Basis Salep}

Pembuatan basis salep dilakukan dengan cara mencampurkan minyak bulu domba dan vaselin album hingga homogen.

Pembuatan Salep

Pembuatan salep ekstrak cangkang telur dan ekstrak tanaman yodium dilakukan dengan cara basis salep ditambahkan ekstrak sedikit demi sedikit hingga homogen dan membentuk salep. Sediaan salep yang akan dibuat dalam penelitian ini memiliki konsentrasi ekstrak cangkang telur dan tanaman yodium, yaitu $15 \%$, $20 \%$, $25 \%$, dan $30 \%$. Rancangan formula disajikan dalam Tabel 1.

Tabel 1 Rancangan formula salep antiseptik alami

\begin{tabular}{lcccc}
\hline Bahan & \multicolumn{4}{c}{ Formula (\%) } \\
\cline { 2 - 5 } & $\mathbf{1 5}$ & $\mathbf{2 0}$ & $\mathbf{2 5}$ & $\mathbf{3 0}$ \\
\hline Cangkang telur & 7,5 & 10 & 12,5 & 15 \\
Ekstrak tanaman Yodium & 7,5 & 10 & 12,5 & 15 \\
Basis salep & 85 & 80 & 75 & 70 \\
\hline
\end{tabular}

\section{Uji Organoleptik}

Uji organoleptik dilakukan untuk mengetahui kualitas sediaan salep. Kualitas salep yang baik adalah berbentuk sediaan setengah padat, salep berbau khas ekstrak yang digunakan dan berwarna seperti ekstrak (Anief 2013). Uji ini biasanya dilakukan untuk mengetahui secara visual mengenai bau, warna, bentuk sediaan salep.

\section{Uji Daya Sebar}

Uji daya sebar digunakan untuk mengetahui kelunakan sediaan salep antiseptik alami saat dioleskan pada kulit manusia, dan seberapa besar kemampuan salep untuk dapat menyebar sampai konstan atau tidak mengalami penyebaran lagi dengan penambahan beban. Beban yang digunakan pada uji ini mempengaruhi luas penyebaran salep, semakin besar beban yang diberikan maka semakin lebar daya sebar yang dihasilkan (Naibaho et al. 2013).

Uji daya sebar dilakukan dengan memasang sepasang lempeng kaca yang salah satu lempengnya berupa kaca objek. Salep diletakan pada permukaan lempeng kaca sebanyak 0,1 gram. lempeng kaca objek diletakkan di atas salep secara simetris, dengan penambahan beban sebesar $20,30,40$ dan $50 \mathrm{~g}$ diletakkan di atas lempengan kaca objek selama 1 menit, selanjutnya diameter salep diukur dengan 
menggunakan jangka sorong. Diameter pengukuran dilakukan secara melintang, membujur dan menyilang ke kanan dan kiri, kemudian dilakukan pencatatan diameter yang tersebar.

\section{Uji pH}

Pengujian $\mathrm{pH}$ salep dilakukan dengan menimbang salep sebanyak 0,5 $\mathrm{g}$ dan diencerkan dengan $5 \mathrm{ml}$ aquades. Kemudian dimasukkan pH stik selama 1 menit.

\section{Uji Homogenitas}

Uji homogenitas dilakukan untuk mengetahui bahwa basis dan salep tercampur dengan sempurna. Apabila warna merata dan tidak terdapat butirbutir halus pada sediaan krim salep dikatakan homogen (Hernani et al. 2012).

\section{Uji in vivo}

Hewan uji yang digunakan dalam penelitian ini adalah ayam lokal. Sebelum pembuatan luka, hewan yang akan diuji dicukur bulunya didaerah punggung sampai licin, kemudian dibersihkan dengan alkohol $70 \%$ dan dibius lokal dengan metode intra dermal. Selanjutnya dibuat luka sayatan dengan ukuran panjang $1,5 \mathrm{~cm}$.

Pengumpulan data pada penelitian adalah sebagai berikut:

a. Ayam lokal dibuat luka, kemudian diukur luas luka awal sebelum dilakukan perlakuan. b. Terdapat 7 perlakuan dan masing masing memiliki 4 ulangan.

\section{Model Analisis Statistik}

Model analisis statistik yang digunakan dalam pengujian ini, yaitu dengan uji Anova (Analysis of variance), apabila berbeda nyata, maka akan dilanjutkan dengan uji lanjut Duncan Multiple Range Test (DMRT).

\section{HASIL DAN PEMBAHASAN}

Sediaan salep dibuat dalam konsentrasi ekstrak kental tanaman yodium dan serbuk cangkang telur yang berbeda-beda, yaitu 15\%, 20\%, 25\% dan $30 \%$. Masing masing formula diuji penjaminan mutu dengan menggunakan uji organoleptik, uji daya sebar, uji pH, uji homogenitas dan uji in vivo.

\section{Uji Organoleptik}

Hasil pengamatan menunjukkan bahwa keempat formula menghasilkan warna hijau tua dengan bentuk krim, bertekstur lembut serta memiliki aroma khas ekstrak. Gambar formulasi sediaan salep dapat dilihat pada Gambar 1.

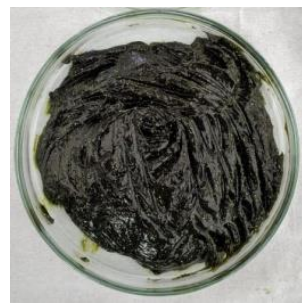

(a)

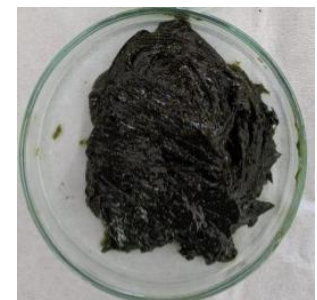

(b) 


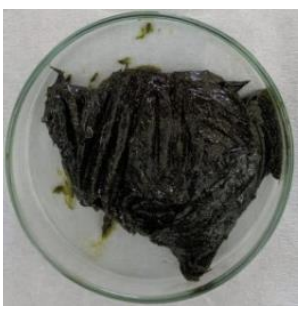

(c)

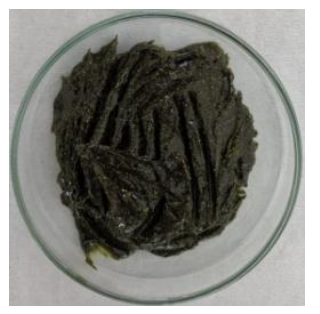

(d)
Gambar 1 Formulasi sediaan salep ekstrak tanaman yodium dan cangkang telur $(\mathrm{a}=$ $15 \%, b=20 \%, c=25 \%, d=30 \%$ )
Secara umum masing masing formula sediaan salep telah menunjukan kualitas salep yang baik. Menurut Anief (2013) kualitas salep yang baik adalah berbentuk sediaan setengah padat, salep berbau khas ekstrak yang digunakan dan berwarna seperti ekstrak. Hasil pengamatan secara organoleptik dapat dilihat pada Tabel 2.

Tabel 2 hasil pengamatan sediaan salep secara organoleptik

\begin{tabular}{lcccc}
\hline Uji & \multicolumn{4}{c}{ Formula (\%) } \\
\cline { 2 - 5 } & $\mathbf{1 5}$ & $\mathbf{2 0}$ & $\mathbf{2 5}$ & $\mathbf{3 0}$ \\
\hline Warna & Hijau tua & Hijau tua & Hijau tua & Hijau tua \\
Aroma & Harum & Harum & Harum & Harum \\
Bentuk & Krim & Krim & Krim & Krim \\
Tekstur & Lembut & Lembut & Lembut & Lembut \\
\hline
\end{tabular}

\section{Uji Daya Sebar}

Menurut Naibaho et al. (2013) menyatakan bahwa uji daya sebar digunakan untuk mengetahui kelunakan sediaan salep antiseptik alami saat dioleskan pada kulit manusia, dan seberapa besar kemampuan salep untuk dapat menyebar sampai konstan atau tidak mengalami penyebaran lagi dengan penambahan beban. Beban yang digunakan pada uji ini mempengaruhi luas penyebaran salep, semakin besar beban yang diberikan maka semakin lebar daya sebar yang dihasilkan. Uji daya sebar pada salep dilakukan untuk melihat kemampuan sediaan menyebar pada kulit, dimana suatu basis salep sebaiknya memiliki daya sebar yang baik untuk menjamin pemberian bahan obat yang baik (Naibaho et al. 2013). Gambar formulasi sediaan salep dapat dilihat pada Gambar 2

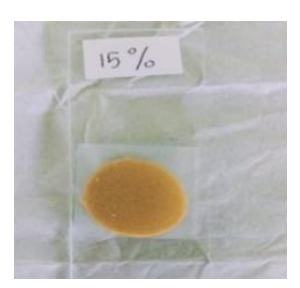

(a)

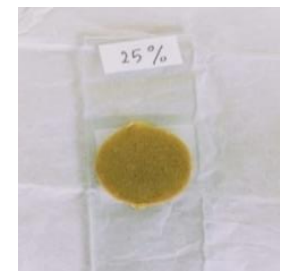

(c)

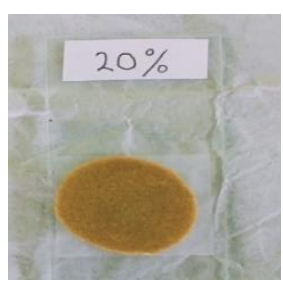

(b)

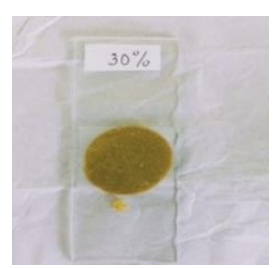

(d)
Gambar 2 Uji daya sebar salep ekstrak tanaman yodium dan cangkang telur $(\mathrm{a}=$ $15 \%, b=20 \%, c=25 \%, d=30 \%$ )

Uji daya sebar pada sediaan salep dilakukan untuk mengetahui 
kemampuan penyebaran salep pada kulit. Semakin mudah salep diratakan pada kulit maka akan semakin memperluas area kulit dan absorpsi zat aktifnya semakin besar. Hasil pengujian dapat dilihat pada Tabel 3.

Tabel 3 Hasil pengamatan uji daya sebar pada sediaan salep

\begin{tabular}{lcccc}
\hline \multirow{2}{*}{ Beban } & \multicolumn{4}{c}{ Diameter daya sebar (cm) } \\
\cline { 2 - 5 } & $\mathbf{1 5}$ & $\mathbf{2 0}$ & $\mathbf{2 5}$ & $\mathbf{3 0}$ \\
\hline Hanya cover glass & 1,3 & 1,4 & 1,5 & 1,6 \\
Beban 20 gr & 1,7 & 1,6 & 1,6 & 1,6 \\
Beban 30 gr & 1,8 & 1,7 & 1,7 & 1,7 \\
Beban 50 gr & 1,9 & 1,8 & 1,7 & 1,8 \\
Beban 100 gr & 1,9 & 1,8 & 1,7 & 1,8 \\
\hline
\end{tabular}

Berdasarkan hasil pengamatan, didapatkan bahwa sediaan semakin melebar karena besar beban yang diberikan terhadap sediaan salep semakin besar. Pengujian daya sebar untuk setiap sediaan salep dilakukan untuk melihat kemampuan sediaan menyebar pada kulit, dimana suatu dasar salep sebaiknnya memiliki daya sebar yang baik untuk menjamin pemberian bahan obat yang memuaskan. Perbedaan daya sebar sangat berpengaruh pada kecepatan difusi zat aktif dalam melewati membran. Semakin luas membran tempat sediaan menyebar maka koefisien difusi makin besar yang mengakibatkan difusi obat pun semakin meningkat, sehingga semakin besar daya sebar suatu sediaan maka makin baik (Hasyim et al. 2012).
Pengujian $\mathrm{pH}$ sediaan salep cangkang telur dan ekstrak tanaman yodium dapat dilihat pada Gambar 3.

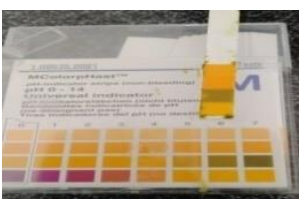

(a)

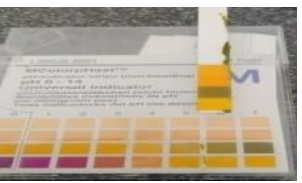

(c)

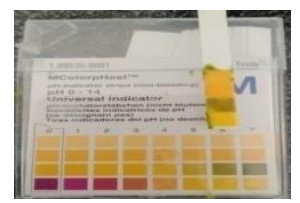

(b)

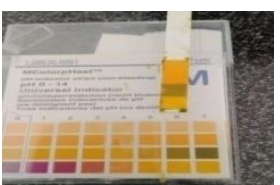

(d)
Gambar 3 Uji pH salep ekstrak tanaman yodium dan cangkang telur $(a=15 \%, b=20 \%, c=25 \%$, $d=30 \%$ )

Persyaratan $\mathrm{pH}$ sediaan topikal yaitu 4,5-6,5 sebab $\mathrm{pH}$ kulit normal memiliki rentang $\mathrm{pH}$ tersebut (Anief, 2006). Hasil pemerikasaan $\mathrm{pH}$ salep memiliki nilai $\mathrm{pH}$ yang sama yaitu 6 , Sehingga dapat disimpulkan bahwa sediaan salep aman untuk digunakan. Hasil dari uji pH dapat dilihat pada Tabel 4.

\section{Uji pH}


Tabel 4 Hasil uji pH pada formulasi salep cangkang telur dan ekstrak tanaman yodium

\begin{tabular}{lc}
\hline Formulasi & Nilai pH \\
\hline $15 \%$ & 6 \\
$20 \%$ & 6 \\
$25 \%$ & 6 \\
$30 \%$ & 6 \\
\hline
\end{tabular}

Uji Homogenitas

Pengujian

homogenitas

menunjukkan bahwa basis dan sediaan salep tidak mengalami perubahan fisik dalam hal homogenitasnya. Hasil uji homogenitas dapat dilihat pada Gambar 4. Hal ini menyatakan bahwa baik basis maupun sediaan salep stabil secara homogenitas dan seluruh bahan yang terkandung dalam formula terdistribusi secara merata.

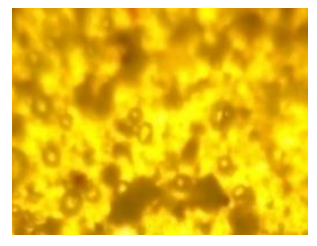

(a)

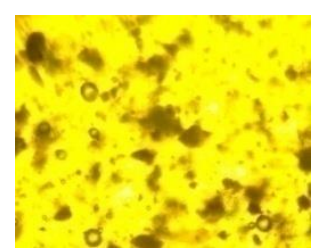

(c)

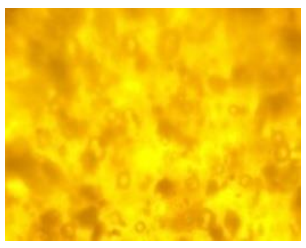

(b)

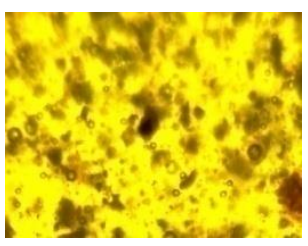

(d)
Gambar 4 Uji Homogenitas salep ekstrak tanaman yodium dan cangkang telur $(\mathrm{a}=15 \%$, $b=20 \%, c=25 \%, d=30 \%$ )

Hal ini disebabkan pada proses pembuatannya, semua bahan yang digunakan untuk pembuatan basis dan salep tercampur dengan sempurna sehingga menghasilkan produk yang homogen. Apabila warna merata dan tidak terdapat butir-butir halus pada sediaan krim salep dikatakan homogen (Hernani et al. 2012). Hasil uji homegenitas dapat dilihat pada Tabel 5.

Tabel 5 Hasil Homogenitas salep

\begin{tabular}{lc}
\hline Formulasi & Hasil \\
\hline $15 \%$ & Tidak Homogen \\
$20 \%$ & Tidak Homogen \\
$25 \%$ & Tidak Homogen \\
$30 \%$ & Tidak Homogen \\
\hline
\end{tabular}

\section{Uji In Vivo}

Hasil pengukuran rata-rata panjang luka untuk semua kelompok perlakuan pada hari ke-1 sampai hari ke14 memperlihatkan perubahan panjang luka yang berkurang. Pengujian aktivitas penyembuhan luka sediaan salep terhadap ayam lokal dapat dilihat pada Gambar 5.

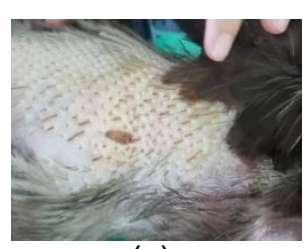

(a)

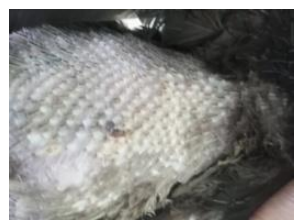

(c)

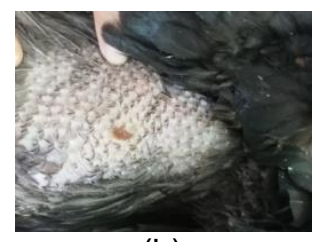

(b)

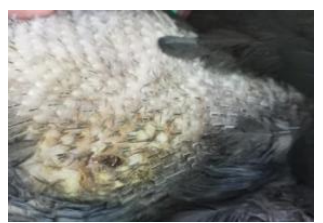

(d) 


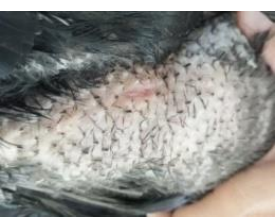

(e)

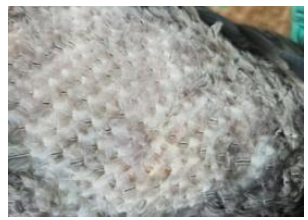

(g)

Gambar 5 Pengujian aktivitas penyembuhan luka sediaan salep terhadap ayam lokal (a : Luka tanpa perlakuan, $\mathrm{b}$ : luka dengan diberi dasar salep, c : luka dengan diberi salep komersial, d : formula salep $15 \%$, e : formula salep $20 \%$, f : formula salep $25 \%, \mathrm{~g}$ : formula salep $30 \%$ ).

Dari hasil pengamatan selama 14 hari, panjang luka dari hari ke-1 sampai hari ke-14 mengalami penurunan, kelompok ayam lokal tanpa perlakuan (LTP) pada hari ke 14 luka sayat masih cukup panjang. Pada kelompok yang diberi dasar salep pada hari ke 14 masih cukup panjang tetapi lebih baik dibandingkan dengan kelompok LTP. Pada kelompok yang diberi salep komersial, salep dengan konsentrasi $20 \%$ dan salep dengan konsentrasi $25 \%$ menunjukan hasil akhir yang sama. Sedangkan kelompok ayam lokal yang diberi sediaan salep dengan konsentrasi $15 \%$ menunjukan hasil yang berbeda tetapi lebih baik apabila dibandingkan dengan kelompok LTP dan kelompok yang diberi dasar salep, sementara kelompok yang diberi salep dengan konsentrasi $30 \%$ merupakan kelompok yang paling cepat sembuh dan menunjukkan penurunan yang paling signifikan.

Tabel 6 Hasil Pengujian aktivitas penyembuhan luka sediaan salep terhadap ayam lokal selama 14 hari

\begin{tabular}{cccccccc}
\hline Hari ke- & \multicolumn{7}{c}{ Panjang luka (cm) } \\
\cline { 2 - 8 } & LTP & DS & SK & $\mathbf{1 5 \%}$ & $\mathbf{2 0 \%}$ & $\mathbf{2 5 \%}$ & $\mathbf{3 0 \%}$ \\
\hline 1 & 1,5 & 1,5 & 1,5 & 1,5 & 1,5 & 1,5 & 1,5 \\
2 & 1,5 & 1,5 & 1,42 & 1,42 & 1,42 & 1,4 & 1,37 \\
3 & 1,45 & 1,4 & 1,35 & 1,3 & 1,25 & 1,25 & 1,15 \\
4 & 1,37 & 1,3 & 1,22 & 1,27 & 1,1 & 1,12 & 1,02 \\
5 & 1,3 & 1,12 & 0,95 & 1,22 & 0,92 & 1 & 0,87 \\
6 & 1,22 & 1,07 & 0,85 & 1,1 & 0,85 & 0,9 & 0,75 \\
7 & 1,2 & 1,02 & 0,77 & 1,02 & 0,77 & 0,8 & 0,67 \\
8 & 1,12 & 0,97 & 0,72 & 0,92 & 0,7 & 0,67 & 0,57 \\
9 & 1,07 & 0,9 & 0,6 & 0,8 & 0,55 & 0,57 & 0,45 \\
10 & 0,97 & 0,77 & 0,47 & 0,7 & 0,45 & 0,5 & 0,35 \\
11 & 0,87 & 0,67 & 0,35 & 0,6 & 0,35 & 0,37 & 0,25 \\
12 & 0,82 & 0,6 & 0,27 & 0,5 & 0,22 & 0,25 & 0,12 \\
13 & 0,75 & 0,52 & 0,1 & 0,35 & 0,1 & 0,15 & 0,07 \\
14 & 0,67 & 0,45 & 0,05 & 0,27 & 0,05 & 0,05 & 0 \\
\hline
\end{tabular}

Keterangan : LTP $=$ Luka Tanpa Perlakuan, DS $=$ Dasar Salep, SK = Salep Komersial 
Pada penelitian ini menunjukkan bahwa salep ekstrak yodium 30\%, 20\% dam $25 \%$ mempunyai efek yang lebih efektif dibandingkan dengan salep komersial. Tanaman Yodium mengandung zat aktif yang mampu mempercepat proses penyembuhan luka sayat, hal ini disebabkan tanaman yodium mengandung saponin, flavanoid, tanin, dan steroid. Dimana saponin berfungsi sebagai pembersih dan antiseptik yang berguna untuk membunuh dan mencegah pertumbuhan mikroorganisme (Hidayat 2017). Flavanoid dapat berfungsi sebagai antimikroba, antivirus dan dapat menghambat pendaharan pada kulit (Hidayat 2017).

Tabel 7 Hasil uji Duncan pada 7 perlakuan

\begin{tabular}{lccc}
\hline Perlakuan & \multicolumn{3}{c}{ Rata-rata } \\
\cline { 2 - 4 } & $0,655^{a}$ & $\mathbf{2}$ \\
\hline $30 \%$ Ekstrak & $0,732^{a}$ & & \\
$20 \%$ Ekstrak & $0,753^{a}$ & & \\
$25 \%$ Ekstrak & $0,760^{a}$ & $0,987^{c}$ \\
Salep Komersial & & $1,132^{c}$ \\
$15 \%$ Ekstrak & $0,928^{b}$ & $1,987^{b c}$ \\
Dasar Salep & & \\
Luka Tanpa & & \\
Perlakuan & & \\
Keterangan : Superscript yang berbeda pada setiap kolom perlakuan menunjukkan perbedaan \\
\multicolumn{2}{l}{ yang signifikan (P<0,05). }
\end{tabular}

Berdasarkan uraian tersebut salep berlemak vaselin album yang menunjukkan bahwa zat aktif yang dapat menarik lebih banyak air sehingga terkandung dalam salep ekstrak yodium luka cepat kering, tidak membusuk dan dapat meningkatkan aliran darah ke luka menutupi luka. Berdasarkan uraian dan juga dapat menstimulus fibroblas sebagai respon untuk penyembuhan luka. Selain itu, kandungan kalsium karbonat $\left(\mathrm{CaCO}_{3}\right)$ dan glukosamin pada cangkang telur merupakan berfungsi meningkatkan produksi asam hialuronat pada fase proliferasi penyembuhan luka. Glukosamin juga terlibat dalam proses stimulasi sintesis glikosaminoglikan dan kolagen pada penyembuhan luka. Basis tersebut menunjukkan bahwa zat aktif yang terkandung dalam salep ekstrak tanaman yodium dan cangkang telur dapat meningkatkan aliran darah ke luka dan juga dapat menstimulus fibroblas sebagai respon untuk penyembuhan luka.

Analisis variasi one way terhadap penurunan panjang luka sayat digunakan untuk melihat ada tidaknya perbedaan 
pengaruh salep yakni salep dengan ekstrak tanaman yodium dan cangkang telur dengan konsentrasi 15\%, 20\%, 25\%, 30\% serta salep komersial, dasar salep dan tanpa perlakuan. Hasil analisis data dari ketujuh kelompok tersebut menunjukkan salep ekstrak tanaman yodium berpengaruh nyata terhadap penyembuhan luka karena menunjukan hasil $F$ hitung $>F$ tabel $(9,59>2,57)$ dan sig $(P<0,05)$.

Berdasarkan Uji Duncan ketujuh perlakuan yang terdiri dari empat ulangan berbeda nyata, dimana salep ekstrak tanaman yodium dan cangkang telur dengan konsentrasi $30 \%$ merupakan perlakuan yang paling efektif dan berpengaruh terhadap proses penyembuhan luka sayat, kemudian disusul salep ekstrak tanaman yodium dan cangkang telur $20 \%, 25 \%$, salep komersial, salep 15\%, dasar salep dan yang terakhir adalah luka tanpa perlakuan. Penyembuhan luka merupakan proses kembalinya fungsi jaringan dan sel dari kondisi perlukaan hingga mencapai fungsi normal (Yunus 2015). Dalam penelitian ini dibuktikan bahwa salep ekstrak tanaman yodium dan cangkang telur $30 \%$, 20\% dan $25 \%$ dapat mempercepat penyembuhan luka lebih baik dibandingkan dengan salep komersial.

\section{PENUTUP \\ Simpulan}

Simpulan dari penelitian ini adalah :

1. Salep yang dibuat dari limbah cangkang telur dan tanaman yodium (Jatropha multifida Linn) dapat dijadikan sebagai pengganti salep komersial, ini dibuktikan dalam penelitian uji secara in vivo yang menunjukan hasil penyembuhan menggunakan salep cangkang telur dan tanaman yodium lebih baik dibandingkan dengan salep komersial.

2. Salep dengan formulasi $30 \%$ merupakan salep dengan dosis terbaik untuk digunakan karena menunjukan hasil penyembuhan luka yang paling cepat.

\section{Saran}

Perlu dilakukan uji aktivitas antibakteri secara in vitro untuk mengetahui tingkat kekuatan zona hambat dari ekstrak tanaman yodium.

\section{DAFTAR PUSTAKA}

Anief, M. 2013. IImu Meracik Obat: Teori dan Praktik ke 16. Yogyakarta: Gadjah Mada University Press.

Anief, M. 2006. IImu Meracik Obat. Yogyakarta: Gadjah Mada University Press

Anonim. 2000. Inventaris Tanaman Obat Indonesia (1) jilid 1. Jakarta: Departemen Kesehatan dan 
Kesejahteraan Sosial RI, Badan

Penelitian dan Pengembangan

Kesehatan.

BPS. 2018. Produksi telur ayam petelur menurut provinsi. diakes pada tanggal 26 Desember 2019 di https://bps.go.id/linkTableDina mi s/view/id/1079.

Depkes RI. 2000. Inventaris Tanaman Obat Indonesia (I) Jilid 1. Jakarta: Departemen Kesehatan dan Kesejahteraan Sosial RI, Badan Penelitian dan Pengembangan Kesehatan.

Hariana, A. 2013. 262 Tumbuhan Obat dan Khasiatnya Edisi Revisi. Jakarta: Penerbar Swadaya.

Hasyim, N., K. L. Pare, I. Junaid, A. Kurniati. 2012. Formulasi dan Uji Efektivitas Gel Luka Bakar Ekstrak Daun Cocor Bebek (Kalanchoe pinnata L.) pada Kelinci (Oryctolagus cuniculus). Majalah Farmasi dan Farmakologi. 16(2): 89-94.

Hernani, M. Y. 2012. Formulasi Salep Ekstrak Air Tokek (Gekko gecko) Untuk Penyembuhan Luka, Jurnal Penelitian Farmasi. Universitas Wahid Hasyim, Semarang.

Hidayat, A. A. 2017. Metode Penelitian Keperawatan dan Kesehatan. Jakarta: Salemba
IImi, A. N. 2009. Tanaman Yodium Jatropha multifida sebagai Bahan Fortifikasi Bath (Abstrak). Karya Tulis IImiah Strata Satu. Surabaya: Fakultas Sains dan Teknologi Universitas Airlangga.

Naibaho, O. H., Yamlean, P.V.Y., Wiyono, W. 2013. Pengaruh Basis Salep Terhadap Formulasi Sediaan Salep Ekstrak Daun Kemangi (Ocimum sanctum L.) Pada Kulit Punggung Kelinci Yang Dibuat Infeksi Staphylococcus aureus, Jurnal IImiah Farmasi, Vol. 2 No. 02.

Rokhana dan Ainiyah. 2019. Potensi Batang Tanaman Yodium (Jatropha multifida Linn) Sebagai Senyawa Anti Bakteri Staphylococcus aureus ATCC 25923 secara in vitro. Akademi Farmasi. Vol. 3, No. 1, Halaman 3.

Sariyana, Nofriani, A., Sabarwati H., Sahidin. 2018. Uji Toksisitas Akut dan Gambaran Hispatologi Hepar Mencit Jantan (Mus musculus L.) yang Diberi Ekstrak Terpurifikasi Daun Galing (Cayratia trifolia L. Domin). Pharmauho Volume 4, No. 1, Hal. 22-25 
Suprapti, L. M. 2002. Pengawetan Telur, Telur Asin Tepung Telur, dan Telur Beku. Yogyakarta: Kanisius.

Warsy, Chadijah S., Rustiah W. 2013. Optimalisasi Kalsium Karbonat dari Cangkang Telur untuk Produksi Pasta Komposit. Jurnal Al-Kimia. Vol. 4(2): 87.

Yunus, B. 2015. Faktor-Faktor Yang Mempengaruhi Lama Penyembuhan Luka Pada Pasien Ulkus Diabetikum Di rumah Perawatan ETN Centre Makassar: Fakultas Kedokteran dan IImu Kesehatan UIN Alauddin Makassar. 